\title{
A survey of an ectotrophic sand dune forest in the northeast Brazil
}

\section{Sulzbacher $\mathrm{MA}^{1^{*}}$, Giachini $\mathrm{AJ}^{2}$, Grebenc $\mathrm{T}^{3}$, Silva $\mathrm{BDB}^{4}$, Gurgel $\mathrm{FE}^{5}$, Loiola MIB $^{6}$, Neves MA ${ }^{7}$ and Baseia IG $^{4}$}

\author{
${ }^{1}$ Universidade Federal de Pernambuco, Departamento de Micologia/CCB, Av. Prof. Nelson Chaves, s/n, CEP: 50670- \\ 901, Recife, PE, Brazil \\ ${ }^{2}$ Departamento de Microbiologia, Imunologia e Parasitologia, Universidade Federal de Santa Catarina, CEP: 88040 - \\ 970, Florianopolis, SC, Brazil \\ ${ }^{3}$ Slovenian Forestry Institute, Vecna pot 2, Ljubljana, Slovenia \\ ${ }^{4}$ Departamento de Botânica, Ecologia e Zoologia, Universidade Federa do Rio Grande do Norte, Campus \\ Universitário, CEP: 59072-970, Natal, RN, Brazil \\ ${ }^{5}$ Instituto Federal de Educação, Ciência e Tecnologia do Rio Grande do Norte, CEP: 59015-300, Natal, RN, Brazil \\ ${ }^{6}$ Laboratório de Taxonomia de Angiospermas, Departamento de Biologia, Universidade Federal do Ceará, Campus do \\ Pici, Bloco 906, CEP: 60440-900, Fortaleza, CE, Brazil \\ ${ }^{7}$ Departamento de Botânica, Centro de Ciências Biológicas, Universidade Federal de Santa Catarina, CEP: 88040- \\ 970, Florianopolis, SC, Brazil
}

Sulzbacher MA, Giachini AJ, Grebenc T, Silva BDB, Gurgel FE, Loiola MIB, Neves MA, Baseia IG 2013 - A survey of an ectotrophic sand dune forest in the northeast Brazil. Mycosphere 4(6), 1106-1116, Doi 10.5943/mycosphere/4/6/8

\begin{abstract}
Ectomycorrhizal (ECM) species are poorly known from tropical lowlands of South America. Recent systematic surveys in the reserve Parque Estadual das Dunas do Natal, in the state of Rio Grande do Norte, Brazil, using a purposive sampling approach revealed new and yet undocumented community of ectomycorrhizal fungi in the reserve. Collections made in areas with a ectotrophic tree genera present next to the established walking paths revealed six genera of putative ECM fungi. These fungi belong to the Basidiomycota family Amanitaceae, Boletaceae, Hymenochaetaceae, Russulaceae and Sclerodermataceae, all of which are poorly documented from Brazil. The study contributed to the fungal diversity in an ectotrophic sand dune forest in the northeast Brazil, necessary for better understanding of the role of these organisms and their impact in the ecosystem. Discoveries opened additional questionings about the distribution, ecology and taxonomy of the ectomycorrhizal genera in tropical moist broadleaf forests.
\end{abstract}

Key words - Basidiomycota - ectomycorrhizal fungi - sequestrate fungi - forest reserve - tropical rainforest

\section{Introduction}

Plant families associated with ectomycorrhizal (ECM) fungi in tropical and subtropical moist broadleaf forest regions in Brazil belong primarily to the Nyctaginaceae (Neea, Pisonia, Guapira), Polygonaceae (Coccoloba), and Fabaceae (Caesalpinioideae and Faboideae) (Singer et al. 1983, Singer \& Aguiar 1986, Haug et al. 2004). Additionally, members of the family Gnetaceae (Gnetum) and Sapotaceae (Glyoxylom) were also described as presenting ECM fungi in the Campinarana forests in the Amazon (Singer \& Araújo 1979). 
Until recently, tropical and subtropical moist broadleaf forests were rarely considered for studies on ECM fungi and the knowledge about ECM forests distribution and the related ECM communities is still limited. Worldwide, most surveys and ecological studies on ectomycorrhizal fungi have been done in temperate and boreal regions, especially in the Northern hemisphere (Brundrett 2009, Tedersoo et al. 2010). Exceptions are tropical montane and submontane regions where species of oaks are found (Nixon 2006). Endomycorrhiza, on the other hand, are predominant in tropical ecosystems as tree species common in the lowland forests are typically associated to arbuscular mycorrhizal (AM) fungi (Thomazini 1977, Hogberg 1982). Studies have also confirmed that AM are predominant in Araucaria forests and Atlantic rainforest of Southern Brazil (Andrade et al. 2000).

The presence of ectotrophic tropical forests has been supported by numerous collections of Agaricomycetes obtained from ECM genera in surveys carried out in many tropical regions of the world, both in the high altitudes and lowland forests (Henkel et al. 2002, 2012, Bâ et al. 2012).

Basidiomes of putative ectomycorrhizal fungi have been described to occur related to caesalpinoid species in Africa (Heinemann 1951, Onguene \& Kuyper 2001, Bâ et al. 2012) and in the Guyanas (Henkel et al. 2002, McGuire 2007, Henkel et al. 2012). Above and below ground studies have shown that species of the Dipterocarpaceous forests in Asia are also associated with ECM fungi (Ducousso et al. 2003, Neves et al. 2012). In the Seychelles Islands members of both caesalpinioid and Dipterocarpaceae were found to be associated with ECM fungi (Tedersoo et al. 2007). A rich diversity of ECM fungi was related to the Patagonian temperate forests of Nothofagus species (Nouhra et al. 2012, 2013).

Recently, two new species of Elaphomyces were discovered in the Guyana forests (Castellano et al. 2012) and a new genus of sequestrate basidiomycete, namely Guyanagaster, was found and described from the Pakaraima Mountains of Guyana, using ecological, molecular and morphological data (Henkel et al. 2010). This new genus is a parasite/saprophyte, closely related to Armillaria. On the other hand the two new species of Elaphomyces have been reported for the first time associated with specimens of Fabaceae from the lowland tropics of South America (Castellano et al. 2012). These studies (Henkel et al. 2010, Castellano et al. 2012) show that tropical South American forests are very likely to present a highly unexplored hypogeous fungal diversity.

Singer was the first to report the presence of ectotrophic forests in the lowlands of the Brazilian Amazon (Singer \& Araújo 1979, Singer et al. 1983). Very few studies have been carried out in Brazil to determine the presence of ECM fungi in native forests. For the most, studies on ECM fungi from Brazil have been done in introduced Pinus and Eucalyptus forests (Giachini et al. 2000, Baseia \& Milanez 2002, Giachini et al. 2004, Cortez et al. 2008, Sulzbacher et al. 2010, Cortez et al. 2011), especially in Southern Brazil. Only a few records exist on ECM fungi for Southern Brazil from native, non-planted forests, which were comprehensive reviewed in the work of Sulzbacher et al. (2013). Recent studies in the Northeast of Brazil have reported some putative ECM fungi collected from the Atlantic Rain Forest and the Semi-Arid Region. These include Amanita crebresulcata Bas (Wartchow \& Maia 2007), A. lilloi Singer (Wartchow et al. 2007), A. lippiae Wartchow \& Tulloss (Wartchow et al. 2009), Cantharellus aurantioconspicuus Wartchow \& Buyck (Wartchow et al. 2012), C. protectus Wartchow \& F.G.B. Pinheiro (Pinheiro \& Wartchow 2013), Clavulina amazonensis Corner (Wartchow 2012a), C. incrustata Wartchow (Wartchow 2012b), Lactarius rupestris Wartchow (Wartchow \& Cavalcanti 2010), and Lactifluus dunensis Sá \& Wartchow (Sá et al. 2013).

A common feature found in the Brazilian ECM fungi is the fragmented distribution. In this respect they do not always strictly follow the distribution of their plant symbionts (sensu Halling et al. 2007a, Tedersoo et al. 2007), which may result in high endemism at the species level due to the specific habitats that they occupy (Henkel 1999, Osmundson et al. 2007, Halling et al. 2007b, Fulgenzi et al. 2008, Henkel et al. 2011).

This article aims to report the first records of putative ECM taxa from a survey of epigeous and hypogeous ECM fungi in a newly discovered ectotrophic sand dune forest in the reserve Parque Estadual Dunas do Natal, located in the city of Natal, Rio Grande do Norte state, in the northeast of 
Brazil, representing a part of the widely distributed ectotrophic sand dune forest along the Brazilian Atlantic coast.

\section{Materials \& Methods}

\section{Study site}

The reserve Parque Estadual das Dunas do Natal is located at $05^{\circ} 48^{\prime}$ to $05^{\circ} 53^{\prime} \mathrm{S}$ and $35^{\circ} 09^{\prime}$ to $35^{\circ} 12^{\prime} \mathrm{W}$ in the city of Natal, Rio Grande do Norte state, in the northeast of Brazil. The park has approximately 1172 ha (Fig. 1). The climate is described as tropical humid, with mean annual temperatures close to $25^{\circ} \mathrm{C}$. Average annual precipitation ranges from $800 \mathrm{~mm}$ to $1,500 \mathrm{~mm}$, with a rainy period from March to July. The vegetation has species representative from the Atlantic Forest, as well as species of the Caatinga and the Coastal Tableland forest types. The topsoil is sandy, composed mainly of marine quartz sand, dystrophic, low in fertility, and the landscape is plain with small slopes (Freire 1990).

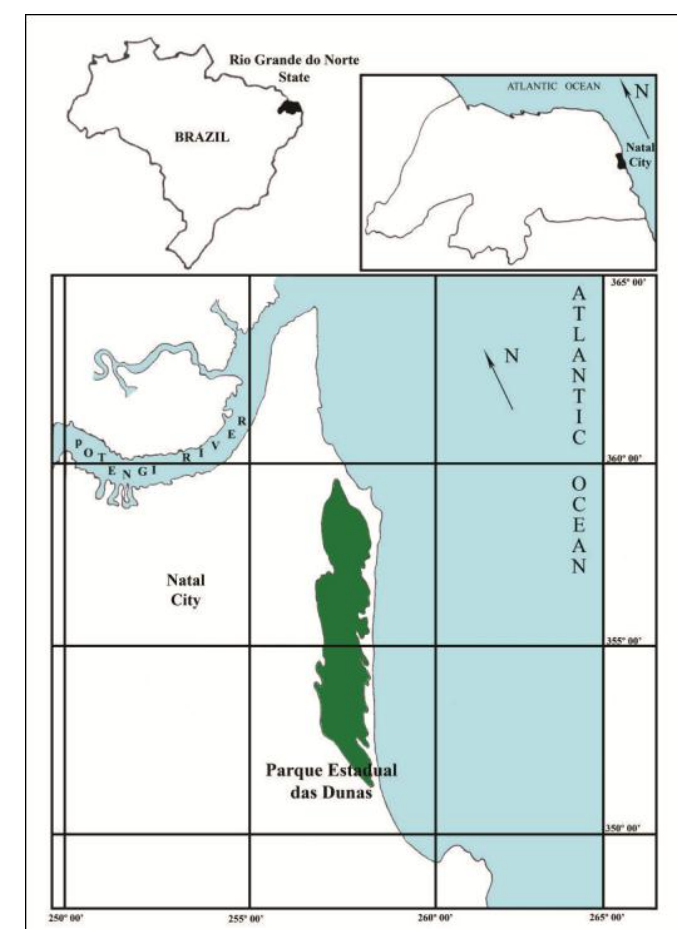

Fig. 1 - Map showing the state of Rio Grande do Norte and the relative location of the Parque Estadual Dunas do Natal (adapted from Freire 1990).

The dense vegetation helps to stabilize the sandy soil of the dunes present in the park. According to the features of the vegetation, as well as edaphic and climatic factors, three vegetation types are recognized in the Park (Freire 1990, Veloso et al. 1991): Coastal Forest or Forest of Littoral Dunes (High forests), beaches and dune foothills (Low forests), and "Restinga" (Fig. 2). The High forests have deep soil and are located in valleys (up to 30 meters in depth) and in between dunes, with trees up to two meters tall. These encompass members such as Bowdichia virgilioides Kunth, Caesalpinia echinata Lam. and Manilkara salzmanii (DC.) Lam. The low forests are formed on fixed dunes, covered by vegetation varying from three to seven meters tall. The low forests are predominantly covered by bushes and small trees such as Eugenia ligustrina (Sw.) Willd., Maytenus erythroxyla Reiss, and Myrcia guianensis DC. "Restinga" is an exposed area at the top of the dunes presenting sandy soil with a high incidence of light and heat. It is also more affected by sea winds. The vegetation is typically composed of Byrsonima gardneriana Juss., Crysobalanus icaco L., Krameria tomentosa A. St. -Hil., and some Cactaceae such as Melocactus spp. and Pilosocereus spp. 


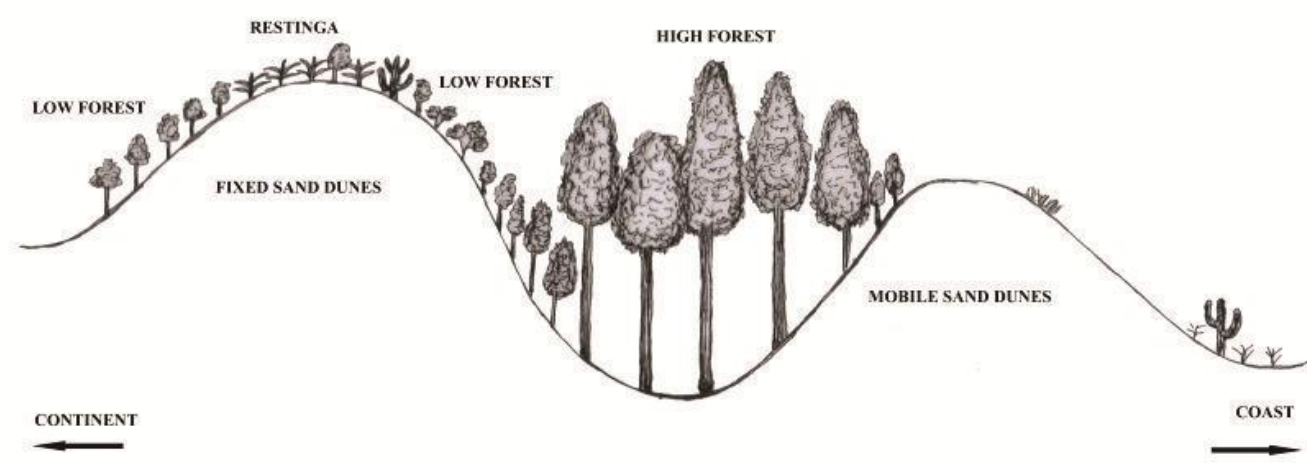

Fig. 2 - Physiognomic regions of Parque Estadual Dunas do Natal (drawing by Tereza Cristina Galvão).

\section{Sampling}

Epigeous basidiomes of putative ECM fungi were collected in designated areas of the Reserve (Fig. 3) using a purposive sampling approach (Schreuder et al. 2004) always close to a potentially ectotrophic tree species. Walking paths were used to determine the survey locations. Surveys were performed during the rainy season in 2007, 2008, 2011 and 2012. In an approach to establish a below ground diversity assessment for the area, hypogeous fungi were collected in the same period using the methodology described by Castellano et al. (2004). All collections were initially assigned to family and further identified to the genus or species level based on the available literature (Dennis 1970, Guzmán 1970, Pegler 1977, 1983, 1986, Singer 1986, Pegler 1997).

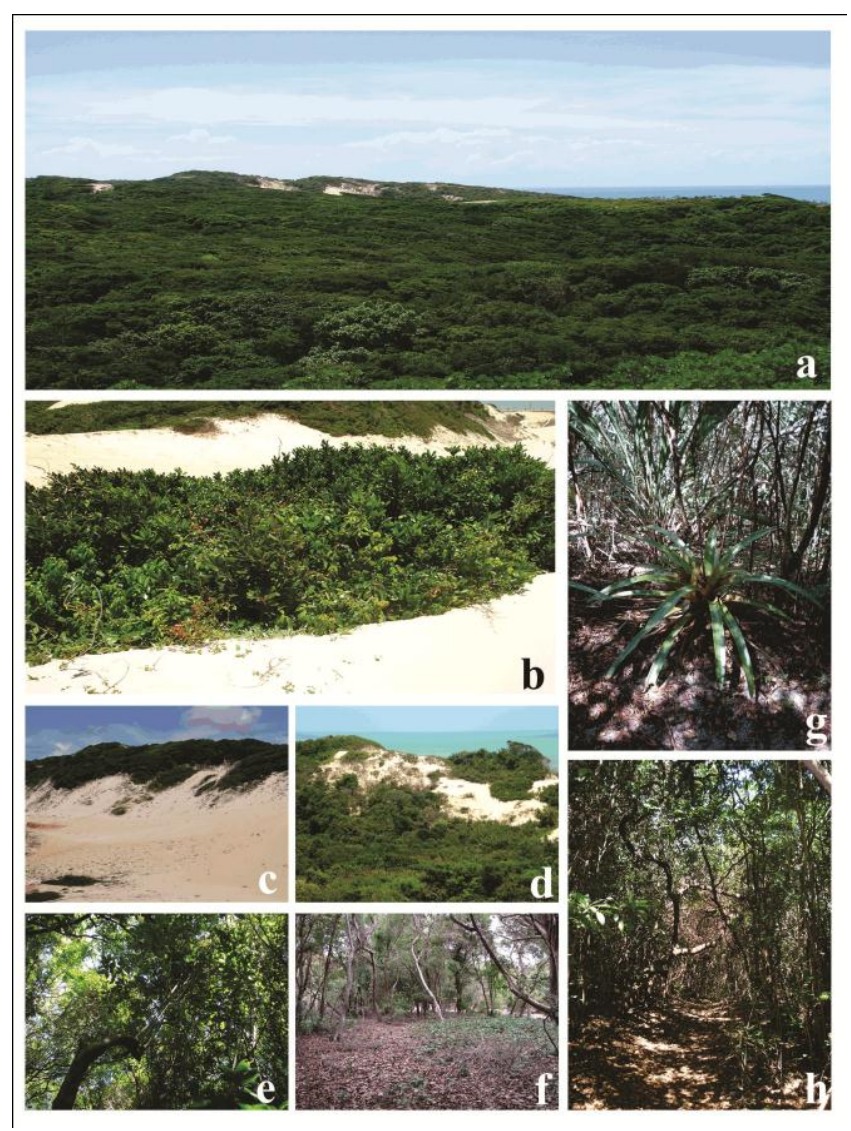

Fig. 3 - Sampling sites at Parque Estadual Dunas do Natal, Rio Grande do Norte, Brazil. a, e, f, g, h show the more arboreal physiognomy of the Atlantic coast restinga vegetation. $b, c, d$ show lowlying shrub restinga vegetation that grows usually on sand dunes, and, thus, receiving direct sea influence. 
The putative ECM status was determined and/or assumed either on the available description of ECM (Agerer 1987-2008, Agerer \& Rambold 2004-2012) or on the taxonomic position (Miller 1983, Singer 1986, Rinaldi et al. 2008, Tedersoo et al. 2010). Specimens were dried according to traditional mycological methodologies (Largent 1986) and deposited as voucher at UFRN herbaria.

\section{Results}

Thirty samples of epigeous/hypogeous basidiomes of putative ectomycorrhizal taxa were collected in all three vegetation types of the park and identified to the genus or species level as described in Table 1. All listed collections were observed growing near native plant species recognized as potential ectomycorrhizal partners. Species occurring in the plots belong to genera such as Amanita, Coltricia, Lactifluus, Russula, Scleroderma and Tylopilus (Fig. 4).
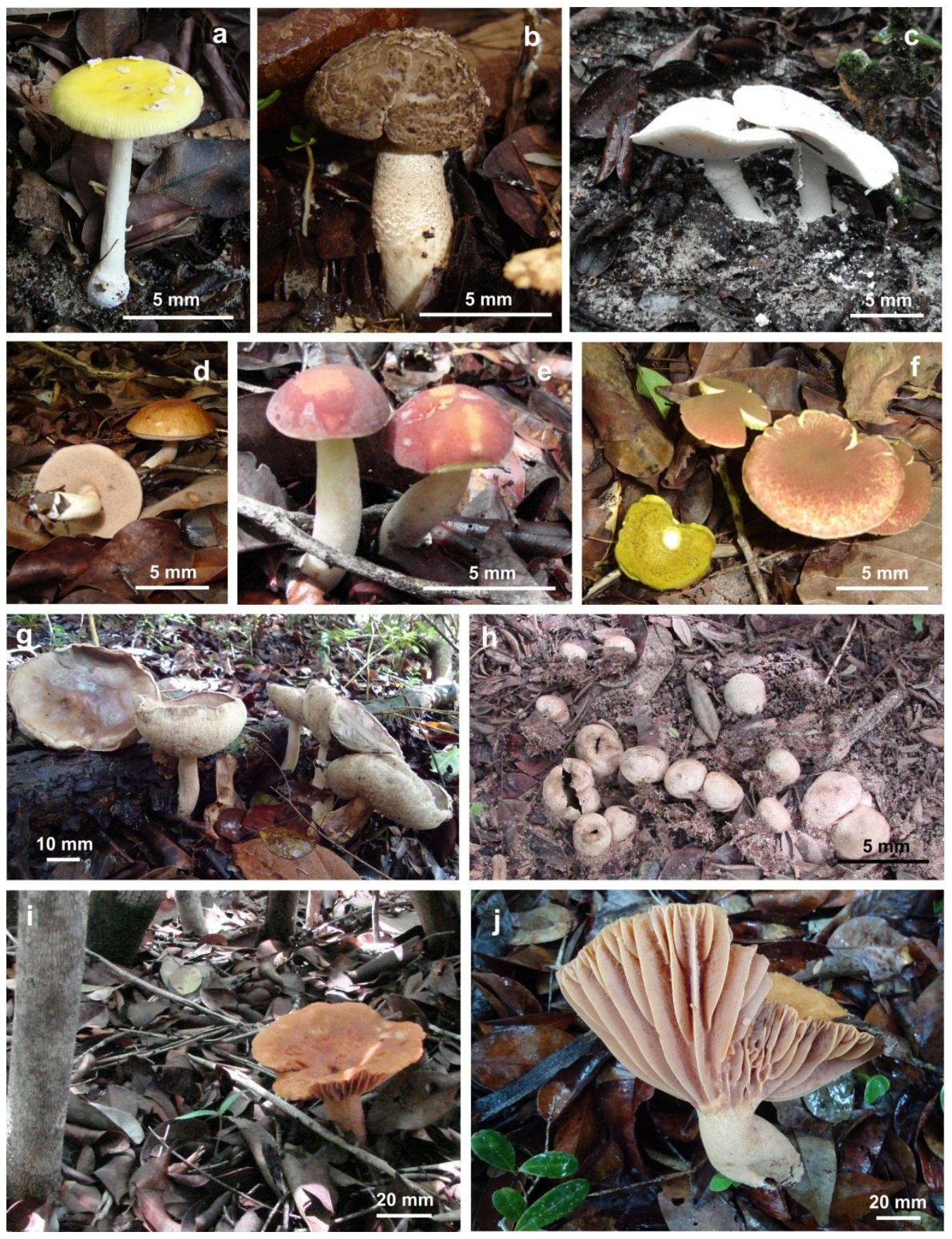

Fig. 4 - Epigeous basidiomes frequently sampled in the Parque Estadual Dunas do Natal. a Amanita viscidolutea, b-c Amanita spp., d-f Boletaceae, g Tylopilus sp., h Scleroderma nitidum, $\mathrm{i}-\mathrm{j}$ Lactifluus spp. 
Table 1 Putative ectomycorrhizal fungal taxa occurring on the Parque Estadual Dunas do Natal, northeast Brazil

\begin{tabular}{|c|c|c|}
\hline Family & Genera & Voucher \\
\hline Amanitaceae & $\begin{array}{l}\text { Amanita sp. } 1 \\
\text { Amanita sp. } 2 \\
\text { Amanita } \mathrm{sp.} 3 \\
\text { Amanita } \mathrm{sp} .4 \\
\text { Amanita } \mathrm{sp} .5 \\
\text { Amanita } \mathrm{sp} .6 \\
\text { Amanita } \mathrm{sp} .7 \\
\text { Amanita sp. } 8 \\
\text { Amanita } \text { sp. } 9 \\
\text { Amanita sp. } 10 \\
\text { Amanita viscidolutea Menolli, } \\
\text { Capelari \& Baseia } \\
\text { Amanita nauseosa (Wakef.) } \\
\text { D.A. Reid }\end{array}$ & $\begin{array}{l}\text { UFRN-fungos } 627 \\
\text { UFRN-fungos } 1870 \text { (Sulzbacher 325) } \\
\text { UFRN-fungos } 1892 \text { (Sulzbacher 349) } \\
\text { UFRN-fungos } 1876 \text { (Sulzbacher 306) } \\
\text { UFRN-fungos } 1880 \text { (Sulzbacher 426) } \\
\text { UFRN-fungos } 1877 \text { (Sulzbacher 427) } \\
\text { UFRN-fungos } 1879 \\
\text { UFRN-fungos } 1878 \\
\text { UFRN-fungos } 1875 \\
\text { UFRN-fungos 942 } \\
\text { UFRN-fungos 958; UFRN-fungos 1872 } \\
\text { (Sulzbacher 307) } \\
\text { UFRN-fungos 1874 (Sulzbacher 309) }\end{array}$ \\
\hline Boletaceae & $\begin{array}{l}\text { Tylopilus sp. } 1 \\
\text { Tylopilus sp. } 2\end{array}$ & $\begin{array}{l}\text { UFRN-fungos } 1158 \\
\text { UFRN-fungos } 1885\end{array}$ \\
\hline Hymenochaetaceae & $\begin{array}{l}\text { Coltricia focicola (Berk. \& } \\
\text { M.A. Curtis) Murrill }\end{array}$ & UFRN-fungos 1893 (Sulzbacher 331) \\
\hline Russulaceae & $\begin{array}{l}\text { Lactifluus sp. } 1 \\
\text { Lactifluus sp. } 2 \\
\text { Lactifluus sp. } 3 \\
\text { Russula } \mathrm{sp} .1 \\
\text { Russula } \mathrm{sp} .2\end{array}$ & $\begin{array}{l}\text { UFRN-fungos } 532 \\
\text { UFRN-fungos } 1873 \text { (Sulzbacher 323) } \\
\text { UFRN-fungos } 1871 \text { (Sulzbacher 326) } \\
\text { UFRN-fungos } 530 \\
\text { UFRN-fungos } 531\end{array}$ \\
\hline Sclerodermataceae & Scleroderma nitidum Berk. & $\begin{array}{l}\text { UFRN-fungos } 762 \text {; UFRN-fungos } 1421 \text {; } \\
\text { UFRN-fungos } 1422\end{array}$ \\
\hline & $\begin{array}{l}\text { Unidentified hypogeous sp. } 1 \\
\text { Unidentified hypogeous sp. } 2 \\
\text { Unidentified hypogeous sp. } 3 \\
\text { Unidentified hypogeous sp. } 4 \\
\text { Unidentified hypogeous sp. } 5 \\
\text { Unidentified hypogeous sp. } 6\end{array}$ & $\begin{array}{l}\text { UFRN-fungos } 1891 \text { (Sulzbacher 334) } \\
\text { UFRN-fungos } 1890 \text { (Sulzbacher 335) } \\
\text { UFRN-fungos } 1888 \text { (Sulzbacher 338) } \\
\text { UFRN-fungos } 1887 \text { (Sulzbacher 350) } \\
\text { UFRN-fungos } 1886 \text { (Sulzbacher 386) } \\
\text { UFRN-fungos } 1889 \text { (Bezerra 07) }\end{array}$ \\
\hline
\end{tabular}

\section{Discussion}

The forests of the reserve Parque Estadual das Dunas do Natal is represented predominantly by trees and shrubs bearing arbuscular mycorrhizal symbionts, since AM is common in tropical and subtropical moist broadleaf forests (Read 1991, Kraigher et al. 2013). On the other hand, Nyctaginaceae, Polygonaceae and Fabaceae from the region have been recognized as potential ectomycorrhizal hosts (Singer et al. 1983, Haug et al. 2004). Field observations showed that, unlike temperate regions, where ECM tree hosts are widely distributed and often dominate the forests, in the reserve the ECM associations were restricted to sharply demarcated stands where Fabaceae/Caesalpinioideae, Myrtaceae, Polygonaceae and Sapotaceae were present. Additionally, a high endemic level of native forests species to this particular ecosystem has also been previously recognized, suggesting it may have evolved co-associated with specific ECM fungal species (Sulzbacher et al. 2013).

The collected fungi from this region belong mainly to Amanita, Lactifluus, Russula and Scleroderma, genera with the broadest host ranges known (Smith \& Read 2008) and frequently reported as ECM partners of Myrtaceae and Polygonaceae (Kreisel 1971, Pegler 1983, Miller et al. 2000, Guzmán et al. 2004, Bandou 2005, Bandou et al. 2006). The ECM fungal community 
registered at the dunes is composed by the same genera found in temperate forests. Although the diversity seems to be considerable high, most collections are still unidentified at the species level. The task of identifing these species is generally arduous due to the lack of well defined vaucher collections and appropriate literature to compare them to.

The results indicate that there is a significant putative ectomycorrhizal fungal community in the Parque Estadual Dunas do Natal. This high diversity found in this preliminary study indicates that additional potential endemic species may be discovered when more sampling efforts are undertaken. Examples of this potentially high levels of endemic species associated to this ecosystem are available. Among them are a recently described species of Amanita viscidolutea (Menolli et al. 2009), and the occurrence of Coltricia focicola (Berk. \& M.A. Curtis) Murrill, a typical ECM species found growing among dead woody debris and litter (Baltazar et al. 2010) in the park. Additionally, Scleroderma nitidum Berk. has been found growing near Coccoloba sp. (Gurgel et al. 2008) and Lactifluus dunensis Sá \& Wartchow was recently described growing on the sandy soil at the dune areas (Sá et al. 2013). Furthermore, it is important to mention that at least one undescribed genus of hypogeous fungi, preliminarily clustered in the Phallales (Basidiomycota), and two new species of putative ECM epigeous agarics and boletes obtained from the park, very likely belonging to Amanita and Tylopilus, are currently being described and will be published elsewhere.

In respect to the hypogeous fungal sporocarps found in the reserve, this is one of the first references to a native hypogeous fungus discovered in Brazil. As pointed out by some authors (Bougher \& Lebel 2001, Claridge 2002), a high number of hypogeous fungi have an obligate ectomycorrhizal association and depend on animals to disperse their spores. It is likely that a wide variety of fungal species with this habit is associated to forests around the world.

The Atlantic Forest is considered one of the 25 hotspots for biodiversity conservation around the globe (Myers et al. 2000), hosting more than 13,700 species of angiosperms (Stehmann et al. 2009), many of them endemic to the region. Consequently, the high diversity of potential ectomycorrhizae tree species suggests a high, unknown diversity of ectomycorrhizal partners. Additional studies focusing on the ECM communities, using basidiomes and ectomycorrhizae, are in need to expand the knowledge about the ECM community and its relationship to the host trees in these tropical broadleaf forest ecosystems.

The role of these putative ectomycorrhizal fungi in the sandy oligotrophic environment of the reserve Parque Estadual das Dunas do Natal is not only to promote the growth of the hosts by improving the capacity to gather nutrients in the poor soil (Read 1998), but also to increase the tolerance to high levels of minerals common in these seawater and coastal influenced zones (Bois et al. 2006). Additionally, it may also protect the plants during dry periods of the year (di Pietro et al. 2007). It has been proved that Scleroderma bermudense can alleviate salt stress in Coccoloba, enhancing considerably the tolerance of the plant species to this mineral (Bandou et al. 2006). Therefore, we predict that some of the ECM fungi occurring in the dunes in Natal may have the same role in the coastal tropic forest ecosystems. These findings agree with Singer \& Araujo (1979) who showed that tropical ECM forests occur in highly oligotrophic white sandy soil ecosystems. This is not always the case since Henkel et al. (2002) found ectotrophic genera that apparently Aldina spp. and Dicymbe spp. do not have clear edaphic requirements. These particular types of plants can occur on different soils ranging from coarse, leached sands to tropical red clays with a wide variety of chemical and textural composition (Henkel et al. 2002).

This study represents a pioneer approach to reveal the potentially high fungal diversity hidden in sandy soils of the "restinga" in the northeast of Brazil. Future studies may uncover the patterns of occurrence and biogeographic distribution of ECM fungi and plants alike in this region. These results represent yet another piece of the puzzle trying to estimate the fungal diversity of tropical regions of Brazil. Surveys on ECM fungi in Brazil and other under-studied sites are necessary to better understand the role of this symbiosis and its impact in the ecosystems. Such discoveries bring about more questions to the discussion on the distribution of the ectomycorrhizal genera of fungi 
and will give hints on the evolutionary placement and overall diversity of this ecologically important group of organisms.

\section{Acknowledgements}

We are grateful to National Council for Scientific and Technological Development (CNPq Brazil) and the Coordination for the Improvement of Higher Education Personnel (CAPES - Brazil) for scholarships granted to the senior author. The work was co-financed by the Brazil - Slovenia bilateral project (BI-BR/11-13-005(SRA) / 490648/2010-0 (CNPq)) and the Research Programme Forest Biology, Ecology and Technology (P4-0107) of the Slovenian Research Agency. The authors would like to thank Domingos Cardoso for contribution to this work, and Tereza Cristina Galvão for the drawing.

\section{References}

Agerer R and Rambold G 2004-2012 [first posted on 2004-06-01; most recent update: 2012-0918]. DEEMY - An Information System for Characterization and Determination of Ectomycorrhizae. www.deemy.de - München, Germany.

Agerer R (Ed.) (1987-2008) Colour Atlas of Ectomycorrhizae 1st-13th Edition. Einhorn-Verlag, Schwäbisch Gmünd, Germany.

Andrade ACS, Queiroz MH, Hermes RAL, Oliveira VL. 2000 - Mycorrhizal status of some plants of the Araucaria forest and the Atlantic rainforest in Santa Catarina, Brazil. Mycorrhiza 10, 131-136.

Baltazar JM, Ryvarden L, Gilbertoni TB. 2010 - The genus Coltricia in Brazil: new records and two new species. Mycologia 102, 1253-1262.

Bandou E. 2005 - Diversité et fonctionnement des symbioses ectomycorhiziennes de Coccoloba uvifera (L.) L. en situation de stress salin et hydrique. Master of Science thesis, UAG, p 36.

Bandou E, Lebailly F, Muller F, Dulormne M, Toribio A, Chabrol J, Courtecuisse R, Plenchette C, Prin Y, Duponnois R, Thiao M, Sylla S, Dreyfus B, Bâ AM. 2006 - The ectomycorrhizal fungus Scleroderma bermudense alleviates salt stress in seagrape (Coccoloba uvifera L.) seedlings. Mycorrhiza 16, 559-565.

Baseia IG, Milanez AI. 2002 - Rhizopogon (Gasteromycetes): hypogeous fungi in exotic forests from the State of São Paulo, Brazil. Acta Bot. Brasil 16, 55-60.

Bâ AM, Duponnois R, Moyersoen B, Diédhiou AG. 2012 - Ectomycorrhizal symbiosis of tropical African trees. Mycorrhiza 22, 1-29.

Bois G, Bigras FJ, Bertrand A, Piche Y, Fung MYP, Khasa DP. 2006 - Ectomycorrhizal fungi affect the physiological responses of Picea glauca and Pinus banksiana seedlings exposed to a NaCl gradient. Tree Physiology 26, 1185-1196.

Bougher NL, Lebel T. 2001 - Sequestrate (Truffle-like) fungi of Australia and New Zealand. Australian Systematic Botany 14, 439-484.

Brundrett MC. 2009 - Mycorrhizal associations and other means of nutrition of vascular plants: understanding the global diversity of host plants by resolving conflicting information and developing reliable means of diagnosis. Plant Soil 320, 37-77.

Castellano MA, Trappe JM, Luoma DL. 2004 - Sequestrate Fungi. In: Mueller GM, Bills GF, Foster MS (eds.) Biodiversity of fungi. Inventory and monitoring methods. Boston, Elsevier Academic Press, pp. 197-213.

Castellano MA, Henkel TW, Miller SL, Smith ME, Aime MC. 2012 - New Elaphomyces species (Elaphomycetaceae, Eurotiales, Ascomycota) from Guyana. Mycologia 104, 1244-1249.

Claridge AW. 2002 - Ecological role of hypogeous ectomycorrhizal fungi in Australian forests and woodlands. Plant and Soil 244, 291-305.

Cortez VG, Baseia IG, Guerrero RT, Silveira RMB. 2008 - Two sequestrate cortinarioid fungi from Rio Grande do Sul State, Brazil. Hoehnea 35, 513-518. 
Cortez VG, Sulzbacher MA, Baseia IG, Antoniolli ZI, Silveira RMB. 2011 - New records of Hysterangium (Basidiomycota) in Eucalyptus plantations of south Brazil. Revista Brasileira de Biociências 9, 220-223.

Dennis RWG. 1970 - Fungus flora of Venezuela and adjacent countries. Kew Bulletin Additional Series 3, 1-531.

di Pietro M, Churin JL, Garbaye J. 2007 - Differential ability of ectomycorrhizas to survive drying. Mycorrhiza 17, 547-550.

Ducousso M, Bena G, Bourgeois C, Buyck B, Eyssartier G, Vincelette M, Rabevohitra R, Randrihasipara L, Dreyfus B, Prin Y. 2003 - The last common ancestor of Sarcolaenaceae and Asian dipterocarp trees was ectomycorrhizal before the India-Madagascar separation, about 88 million years ago. Molecular Ecology 13, 231-236.

Freire SMB. 1990 - Levantamento Florístico do Parque Estadual das Dunas de Natal. Acta Botanica Brasilica 4, 41-59.

Fulgenzi TD, Mayor JR, Henkel TW, Halling RE. 2008 - New species of Boletellus from Guyana. Mycologia 100, 490-495.

Giachini AJ, Oliveira VL, Castellano MA, Trappe JM. 2000 - Ectomycorrhizal fungi in Eucalyptus and Pinus plantations in southern Brazil. Mycologia 92, 1166-1177.

Giachini AJ, Souza LAB, Oliveira VL. 2004 - Species richness and seasonal abundance of ectomycorrhizal fungi in plantations of Eucalyptus dunnii and Pinus taeda in southern Brazil. Mycorrhiza 14, 375-381.

Gurgel FE, Silva BDB, Baseia IG. 2008 - New records of Scleroderma from Northeastern Brazil. Mycotaxon 105, 399-405.

Guzmán G. 1970 - Monografia del género Scleroderma Pers. emend. Fr. (Fungi-Basidiomycetes). Darwiniana 16, 233-407.

Guzman G, Ramirez-Guillén F, Miller OK, Lodge DJ, Baroni TJ. 2004 - Scleroderma stellatum versus Scleroderma bermudense: the status of Scleroderma echinatum and the first record of Veligaster nitidum from the Virgin Islands. Mycologia 96, 1370-1379.

Halling RE, Osmundson TW, Neves MA. 2007a - Pacific boletes: Implications for biogeographic relationships. Mycological Research 112, 437-447.

Halling RE, Baroni TJ, Binder M. 2007b - A new genus of Boletaceae from eastern North America. Mycologia 99, 310-316.

Haug I, Weiß M, Homeier J, Oberwinkler F, Kottke I. 2004 - Russulaceae and Thelephoraceae form ectomycorrhizas with members of the Nyctaginaceae (Caryophyllales) in the tropical mountain rain forest of southern Ecuador. New Phytologist 165, 923-936.

Heinemann P. 1951 - Champignons récoltés au Congo Belge para Madame M. Goossens-Fontana. I. Boletineae. Bulletin du Jardin Botanique de l'Etat. Brussels 21, 223-346.

Henkel TW. 1999 - New taxa and distribution records of Tylopilus from Dicymbe forests of Guyana. Mycologia 91, 655-665.

Henkel TW, Terborgh J, Vilgalys RJ. 2002 - Ectomycorrhizal fungi and their leguminous hosts in the Pakaraima Mountains of Guyana. Mycological Research 106, 515-531.

Henkel TW, Smith ME, Aime CM. 2010 - Guyanagaster, a new wood-decaying sequestrate fungal genus related to Armillaria Agaricales, Basidiomycota. American Journal of Botany 97, 111.

Henkel TW, Aime CM, Uehling JK, Smith ME. 2011 - New species and distribution records of Clavulina (Cantharellales, Basidiomycota) from the Guiana Shield. Mycologia 103, 883-894.

Henkel TW, Aime MC, Chin MML, Miller SL, Vilgalys R, Smith ME. 2012 - Ectomycorrhizal fungal sporocarp diversity and discovery of new taxa in Dicymbe monodominat forests of the Guiana Shield. Biodiversity and Conservation 21, 2195-2220.

Hogberg P. 1982 - Mycorrhizal associations in some woodland and forest trees and shrubs in Tanzania. New Phytologist 92, 407-415.

Kraigher H, Bajc M, Grebenc T. 2013 - Mycorrhizosphere complexity. In Matyssek et al. (eds.) Climate Change, Air Pollution and Global Challenges. Elsevier Academic Press. 
Kreisel K. 1971 - Clave para la identificacion de los macromicetos de Cuba. La Habana: Ser. A, Ciencias Biologicas 16, Universidad de la Habana, p. 101.

Largent DL. 1986 - How to Identify Mushrooms to Genus I: Macroscopic features. I. 2nd ed. Mad River Press Inc., Eureka. 166 pp.

McGuire KL. 2007 - Common ectomycorrhizal networks may maintain monodominance in a tropical rain forest. Ecology 88, 567-574.

Menolli N, Capelari M, Baseia IG. 2009 - Amanita viscidolutea, a new species from Brazil with a key to Central and South American species of Amanita section Amanita. Mycologia 101, 391-396.

Miller OK Jr. 1983 - Ectomycorrhizae in the Agaricales and Gasteromycetes. Can J Bot 61, 909916.

Miller OK Jr, Lodge DJ, Baroni TJ. 2000 - New and interesting ectomycorrhizal fungi from Puerto Rico, Mona, and Guana Islands. Mycologia 92, 558-570.

Myers N, Mittermeier RA, Mittermeier CG, Fonseca GAB, Kent J. 2000 - Biodiversity hotspots for conservation priorities. Nature 403, 853-858.

Neves MA, Binder M, Halling RE, Hibbett DS, Soytong K. 2012. The phylogeny of selected Phylloporus species, inferred from NUC-LSU and ITS sequences, and descriptions of new species from the Old World. Fungal Diversity 55: 109-123.

Nixon, KC. 2006 - Global and neotropical distribution and diversity of oak (genus Quercus) and oak forests. In: M. Kappelle (Ed.) Ecology and Conservation of Neotropical Montane Oak Forest, Ecological Studies Vol 185, Springer-Verlag Berlin Heidelberg.

Nouhra E, Urcelay C, Longo S, Fontenla S. 2012 - Differential hypogeous sporocarp production from Nothofagus dombeyi and N. pumilio forests in southern Argentina. Mycologia 104, 4552.

Nouhra E, Urcelay C, Longo S, Tedersoo L. 2013 - Ectomycorrhizal fungal communities associated to Nothofagus species in Northern Patagonia. Mycorrhiza. doi: DOI 10.1007/s00572-013-0490-2.

Onguene NA, Kuyper TW. 2001. Mycorrhizal associations in the rain forest of South Cameroon. Forest Ecology and Management 140: 277-287.

Osmundson TW, Halling RE, Bakker HCD. 2007 - Morphological and molecular evidence supporting an arbutoid mycorrhizal relationship in the Costa Rican páramo. Mycorrhiza 17, 217-222.

Pegler DN. 1977 - A preliminary Agaric flora of East Africa. Kew Bulletin Additional Series 6, 1615.

Pegler DN. 1983 - Agaric flora of Lesser Antilles. Kew Bulletin Additional Series 9, 1-668.

Pegler DN. 1986 - Agaric Flora of Sri Lanka. Kew Bulletin Additional Series 12, 1-514.

Pegler DN. 1997 - The Agarics from São Paulo. Royal Botanic Garden, Kew, London.

Pinheiro FGB, Wartchow F. 2013 - Cantharellus protectus - a new species from Paraíba, Brazil. Sydowia 65, 27-31.

Read DJ. 1991 - Mycorrhizas in ecosystems. Experientia 47, 376-391.

Read DJ. 1998 - Plants on the web. Nature 396, 22-23.

Rinaldi AC, Comadini O, Kuyper TW. 2008 - Ectomycorrhizal fungal diversity: separating the wheat from the chaff. Fungal Diversity 33, 1-45.

Sá MCA, Baseia IG, Wartchow F. 2013 - Lactifluus dunensis, a new species from Rio Grande do Norte, Brazil. Mycosphere 4, 261-264.

Schreuder HT, Ernst R, Ramirez-Maldonado H. 2004 - Statistical techniques for sampling and monitoring natural resources. Gen. Tech. Rep. RMRS-GTR-126. Fort Collins, CO: U.S. Department of Agriculture, Forest Service, Rocky Mountain Research Station. 111 pp.

Singer R, Araújo I. 1979 - Litter decomposition and ectomycorrhiza in Amazonian forests. 1. A comparison of litter decomposing and ectomycorrhizal basidiomycetes in latosol-terra-firme rain forest and white podzol campinarana. Acta Amazonica 9, 25-41. 
Singer R, Araujo I, Ivory MH. 1983 - Ectotrophically Mycorrhizal Fungi of the Neotropical Lowlands, Especially Central Amazonia. 77. ed. Lubrecht \& Cramer Ltd, 352 pp.

Singer R, Aguiar IA. 1986 - Litter decomposition and ectomycorrhizal Basidiomycetes in an Igapó forest. Plant Systematics and Evolution 153, 107-117.

Singer R. 1986 - The Agaricales in Modern Taxonomy. $4^{\text {th }}$ ed., Koeltz Scientific Books, Stuttgart.

Smith SE, Read DJ. 2008 - Mycorrhizal Symbiosis. 3 ed. Academic Press, 800 pp.

Stehmann JR, Forzza RC, Sobral M, Hamino LHY. 2009 - Gimnospermas e angiospermas. Pg. $27-$ 37. In: Stehmann JR, Forzza RC, Sobral M, Hamino LHY (eds.). Plantas da Floresta Atlântica. Rio de Janeiro, Jardim Botânico do Rio de Janeiro.

Sulzbacher MA, Cortez VG, Coelho G, Jacques RJS, Antoniolli ZI. 2010 - Chondrogaster pachysporus in a Eucalyptus plantations of southern Brazil. Mycotaxon 113, 377-384.

Sulzbacher MA, Grebenc T, Jacques RJS, Antoniolli ZI. 2013 - Ectomycorrhizal fungi from southern Brazil - a literature-based review, their origin and potential hosts. Mycosphere 4, $61-95$.

Tedersoo L, Suvi T, Beaver K, Kõljalg U. 2007 - Ectomycorrhizal fungi of the Seychelles: diversity patterns and host shifts from the native Vateriopsis seychellarum (Dipterocarpaceae) and Intsia bijuga (Caesalpiniaceae) to the introduced Eucalyptus robusta (Myrtaceae), but not Pinus caribea (Pinaceae). The New Phytologist 175, 321-333.

Tedersoo L, May TW, Smith ME. 2010 - Ectomycorrhizal lifestyle in fungi: global diversity, distribution, and evolution of phylogenetic lineages. Mycorrhiza 20, 217-263.

Thomazini LI. 1977 - Mycorrhiza in plants of the cerrado. Plant and Soil 41, 707-711.

Veloso HP, Rangel Filho ALR, Lima JCA. 1991 - Classificação da vegetação brasileira, adaptada a um sistema universal. Rio de Janeiro: IBGE. 124p.

Wartchow F, Maia LC. 2007 - The Neotropical Amanita crebresulcata: new citation from Northeast Brazil. Hoehnea 34, 131-134.

Wartchow F, Tulloss RE, Cavalcanti MAQ. 2007 - The discovery of Amanita lilloi in Brazil. Mycotaxon 99, 167-174.

Wartchow F, Tulloss RE, Cavalcanti MAQ 2009 - Amanita lippiae - a new species from semi-arid caatinga region of Brazil. Mycologia 101: 864-870.

Wartchow F, Cavalcanti MAQ 2010 - Lactarius rupestris - a new species from the Brazilian semiarid region. Mycotaxon 112, 55-63.

Wartchow F, Buyck B, Maia LC 2012 - Cantharellus aurantioconspicuus (Cantharellales), a new species from Pernambuco, Brazil. Nova Hedwigia 94, 129-137.

Wartchow F 2012a - Clavulina amazonensis, an Amazonian fungus discovered in the Atlantic Forest. Kurtziana 37, 113-117.

Wartchow F 2012b - Clavulina incrustata, a new species from Pernambuco, Brazil. Cryptogamie, Mycologie 33, 105-113. 